\title{
THE FUNERAL CULTURE OF ESTONIANS IN THE MINUSINSK REGION, SIBERIA, AS A REPRESENTATION OF THE COMMUNITY AND ITS TRANSFORMATION
}

\author{
Anu Korb
}

\begin{abstract}
The article discusses the death and funeral culture of Estonians inhabiting the Minusinsk region in East Siberia as a representation of the community's solidarity and a sense of belonging, while observing changes in the funeral culture. The majority of Estonians living today in the Minusinsk region are descendants of the peasants who migrated to this area in search of free land in the last quarter of the 19th and at the beginning of the 20th centuries, or were deported from Estonia or forced to settle in Siberia after had been passed the tsar's law in 1845, according to which the region was defined as the Lutheran settlement in East Siberia.

Most of the Estonians who later migrated from urbanised villages to towns remained closely connected with their home village and therefore considered themselves as part of the Estonian community. The funeral culture of Estonians in Siberia is inseparably connected with the Lutheran liturgical tradition and the Estonian language. Regardless of abrupt political changes (the Bolsheviks' return to power, banning of all religious activities, repressions, wars, etc.), religious funerals have survived as part of the tradition. Funeral rituals are officiated by village buriers, who have to pay notice to other community members. The most direct function of such collective ritual practices is to unite the community. The community's funeral practices clearly reflect group identity, attempts to observe ancestral customs, emphasising the importance of helping each other in the community. Along with changes in society, times of crisis, political situation, the influence of multicultural environment, the growing number of mixed marriages, etc., the funerary tradition is also undergoing a transformation.
\end{abstract}

Keywords: community, death and funerary culture, Estonians, identity, multiculturalism, Siberia

\section{SOURCES}

The article explores the changes that have occurred in the funeral culture of Estonians in the Minusinsk region, Siberia, over the past few decades. The analysis of death and funeral customs is largely based on the material collected by the author, who carried out fieldwork in the area from 1991 to 1992 
and, again, a few decades later, from 2012 to 2013. During the 1990s, the author interviewed Estonians living in Siberian villages, and this material constitutes the majority of large-scale thematic interviews. From 2012 to 2013 , the collecting of the material was based on semi-structured interviews about biographical tendencies, supported by participant observation. Interviews of the second period involved, besides villagers, also Estonians who had moved to Siberian cities and towns. The material was collected mainly from middle-aged and older people, thus offering a glance at a somewhat earlier period. In terms of death and funeral culture, the most useful information was obtained from the women who had officiated burials in the village. They were familiar with the death-related tradition and acted as its primary shapers. In addition, the author was given a chance to take part in a funeral that took place in Verkhnii (Upper) Suetuk village in spring 2012.

Observations about the funeral culture of Estonians in the Minusinsk region have also been found in the material collected in earlier times, for example, in the collections of linguists Jüri Viikberg and Lembit Vaba (see, e.g., Viikberg $\&$ Vaba 1984), who visited the same communities in the 1980s. The article also makes use of the material recorded in the 1970s by Rosalie Ottesson, a Siberian correspondent of the Estonian Folklore Archives. Ottesson's descriptions of local death and funeral traditions seemed to be based on a detailed questionnaire entitled "Questions about funerary customs", compiled by Amanda Raadla in 1940 .

\section{TERMINOLOGY AND DEFINITIONS: THEORETICAL CONSIDERATIONS}

Even to this day, Estonians of the Minusinsk region in Siberia clearly stand out among their neighbours. The majority of Estonians who have resettled from villages to cities (e.g., Minusinsk) or the surrounding villages (e.g., Motorskii, Karatuzskoe) have remained closely connected with the people back in the home village, and therefore it is possible to treat them as part of the Estonian community. Cultural studies see the community as a culturally construed phenomenon, which, in addition to statistical connections, presumes to be culturally different from others, or features a sense of unity or belonging, which is suitable for characterising contemporary communities that are more open. The sense of belonging is, in turn, closely connected with the sense of identity. According to Stuart Hall (1999: 248-250), identity is a conscious strategy directed towards the future, serving the aims of a single individual or a group. The sustainability of diaspora communities depends on whether they have succeeded in estab- 
lishing structures that would be parallel to the social institutions of their host country, and how effectively they have maintained them. What is important is the community's collective will to exist as a linguistic-cultural community (Ehala 2010: 68-69), or its ethnolinguistic vitality (Giles \& Bourhis \& Taylor 1977: 307). The sustainability of a community thus depends on the influences of the external environment and the strength and ethnolinguistic vitality of the internal environment (see, e.g., Ehala 2010: 69). A positively perceived external environment (e.g., a naturally isolated habitat, adequate supply of resources) and social circumstances (absence of an imposing monocultural and dominant neighbourhood) have had a positive effect on the sustainability of Estonian village communities in Siberia (Kulu 1992: 57). The late 19th-century policies of Russification did not affect the Siberian Lutheran (among them Estonian) communities as strongly, since the local schools came under the jurisdiction of the village community and the Lutheran Church rather than the state. At the same time, the destructive policies of the Soviet regime have had a lasting negative influence (demolishing the ethnic structure of settlements, banning religious practices, etc.) on the community.

The key function of collective ritual practices is to unite members of the community. Arnold van Gennep (1977 [1960]), who has studied transition rituals, argues that the life of an individual member of the community consists of many transitions and that the individual's social position alters through these transitions. Death brings to the fore the most important community values (Jetsu 2001: 34). Death and funeral culture have been defined as the sum of different views and behaviours related to death (Pentikäinen 1990: 7), but also as a synthesis of death-related beliefs and practices, which is based on social contract (Ristolainen 2004: 11). How an individual perceives death and deathrelated behaviour is shaped under the influence of both community perceptions and external factors (e.g., the media, literature).

The article approaches the funerary and death culture of Estonians in the Minusinsk region as a representation of the solidarity of the community and the individual, a feeling of being part of the group. Rituals have a stabilising role in human relationships, whereas through a ritual an individual becomes aware of his or her identity (Greverus 1987: 258). Several authors, among them Victor Turner (1969), have pointed to the transformation of established social relationships in ritual contexts, in which key positions may be held by people with skills or abilities quite different than those in everyday life. At the same time, societal changes, times of crisis or political situations may abruptly change the function of a tradition in society. 


\section{ON THE HISTORY OF SETTLEMENT AND LATER DEVELOPMENTS}

The first Lutheran congregations in Siberia were founded as early as in the 18th century (Jürgenson 2002: 72). The first records about Estonians who settled in the Minusinsk region date back to the period after the 1845 law, according to which the region was defined as the Lutheran settlement in East Siberia. The population consisted mainly of free peasants who had been deported or forced to emigrate from homeland (Must 2012: 365). The Lutheran Church played a major role in the fact that at least part of the Estonians who had been forced to migrate to Siberia held on to their ethnic religion, language and national identity, and partly also cultural traditions and work ethics (ibid.: 466). Verkhnii Suetuk village became the first Lutheran settlement in the region, and Jüri Kuldem from Tobolsk Guberniia in West Siberia is known as the first person to settle in the village (ibid.: 383). A while later, after the colony became overpopulated, two additional Lutheran settlements were founded - Verkhnaia (Upper) Bulanka and Nizhnaia (Lower) Bulanka. From then on, Verkhnii Suetuk was intended for Finnish settlers, Verkhnaia Bulanka for Estonians and Nizhnaia Bulanka for Latvians and Germans (ibid.: 391-392). In reality, the population in the villages varied all the time, and the number of permanent settlers was rather low. Basic practical religious and educational activities in these Lutheran settlements were carried out by local vicars/schoolmasters, since the pastors' service area was far too broad.

In the final decade of the 19th century and in the early 20th century, the number of Estonians migrating in the course of agrarian colonisation started to grow. By that time, the majority of Estonians in the Minusinsk region were descendants of former emigrants. Ever since the foundation of the settlements, the emigrants complained about withering religious activities on the pages of Estonian newspapers (see, e.g., Postimees 1899: 1), even though there were several talented vicars/schoolmasters (Jaan Nebokat, Jüri Veem, and others) active in the Lutheran settlements of the Minusinsk region in the second half of the 19th and early 20th centuries. Among their responsibilities was the performing of baptising and funeral rituals. Jüri Veem is also known as the founder of a brass band in Verkhnii Suetuk village (Must 2012: 432-440), which has been active until the present day.

Religion has played a vital role in establishing the sense of 'us' group. During the spread of reformation movement in Estonia since the mid-19th century, part of the local population converted to Russian Orthodoxy owing to economic and social conflicts; however, after migrating to Siberia, many of those who had become Orthodox Christians in their homeland chose to reconvert to 


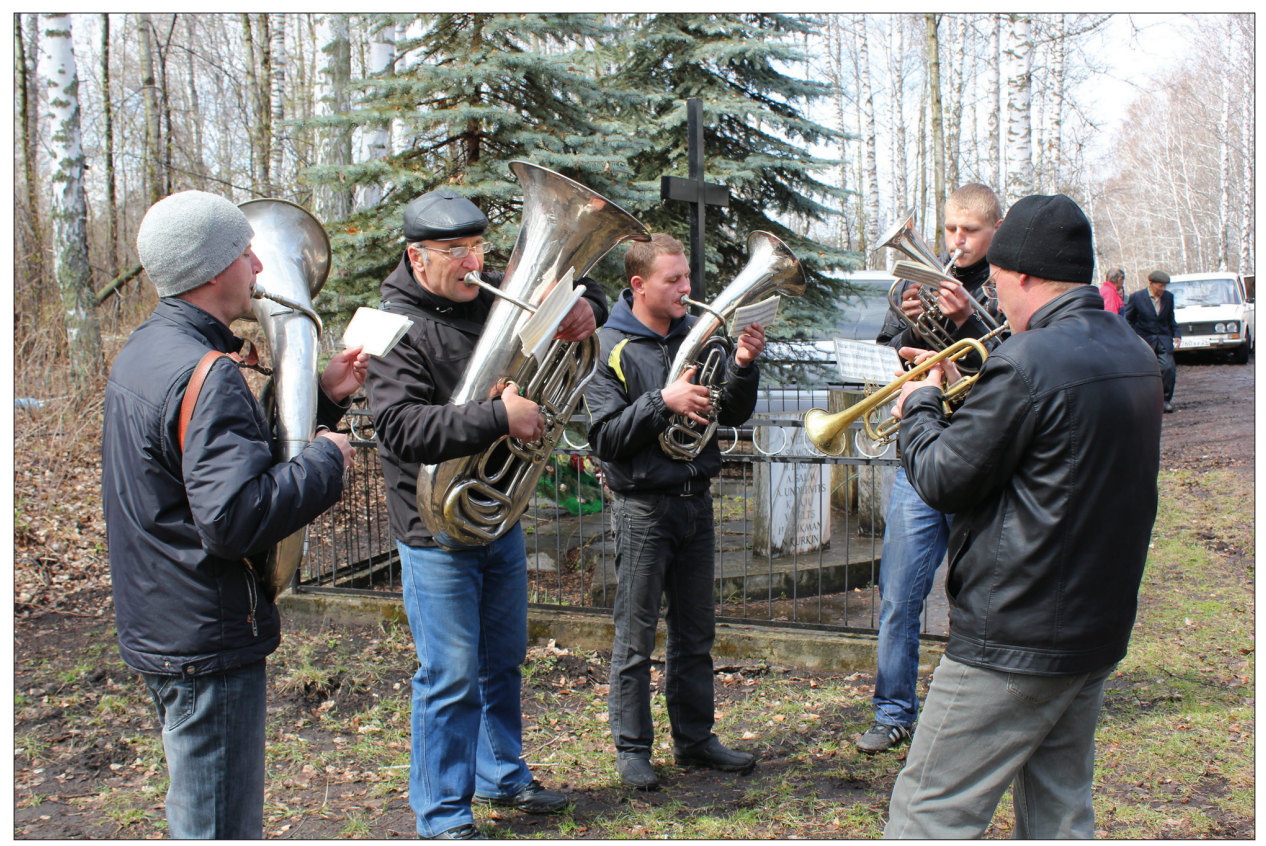

Figure 1. In Verkhnii Suetuk village the deceased is sent off to the accompaniment of brass band music. Photograph by Andreas Kalkun 2012.

Lutheranism (Jürgenson 2002: 228-229). The Estonian settlers have continued to refer to Lutheranism as 'our/Estonian faith'. As compared to the Orthodox, Lutherans of other nationalities (Latvians, Finns, and Germans) were more readily accepted as 'us'. In the events after the Bolsheviks' return to power in 1917, the most entrepreneurial and financially successful people - the socalled kulaks - suffered the most. Religious life, and later also the closing of ethnic schools, repressions and the foundation of collective farms paralysed the established routine in the communities. After the Second World War, larger villages were turned into multi-ethnic settlements, while the population in the villages off the major central roads, such as Verkhnii Suetuk and Verkhnaia Bulanka, continued to decrease as the villagers moved to the cities and towns of Russia and also elsewhere.

Quite a considerable number of those who left the villages of this region decided to relocate within the same province, settling in the city of Minusinsk, the district centre Karatuzskoe, or the surrounding Russian villages. At the same time, during the period that Estonia was annexed by the Soviet Union 
(1940-1941, 1944-1991), there was a mass repatriation to Estonia, the ancestral land, from Siberian villages and settlements. Estonians of the Minusinsk region have traditionally had a relatively close contact with their compatriots in homeland: visiting relatives, keeping up correspondence, sending books, clothing and other goods from Estonia, and cedar seeds, honey, wool, etc. from Siberia. The vastly changed economic situation (hyperinflation, unemployment) and political atmosphere (Estonian-Russian border disputes) after the collapse of the Soviet Union brought an abrupt change also into the lives of Estonians in the Minusinsk region, after which contacts with Estonia lessened considerably (Korb 2008: 56-58). Since the first decade of the 21st century, cross-border communication has become more active, owing to the increasingly frequent visits and rapid technological advances (phone technology, Skype). The Estonians who live in this region of Siberia do not have a socially constructed community, but they meet each other at Lutheran services or social gatherings in the homes of their acquaintances and kin. After all, the Estonian population in Siberia is decreasing.

\section{CHANGES IN FUNERAL CULTURE UNDER THE SOVIET REGIME}

The funeral culture of Estonians in Siberia is inseparable from the Lutheran tradition and the Estonian language. After the Bolsheviks' return to power and the banning of all religious ritual practices, an attempt was made to establish new Soviet traditions, which were national in form but Socialist in content. The aim was to free transition rites from the rule of the Church (see, e.g., Heikkinen 1985: 123). In fact, the Estonians in Siberian village communities never really abandoned the word of God, even at the funerals of party functionaries. In public, people tried to appease the Soviet authorities, but in private they still turned to God. Informant Rosalie Ottesson retrospectively describes the situation in a letter to Igor Tõnurist ${ }^{1}$ in 1967:

Should a Communist or a Komsomol functionary die, they make a cross and a pentangle upon that cross. Today one is buried with an official speech and to revolutionary songs, but tomorrow, when the chapel is empty, a religious father or mother will be summoned to say a prayer and sing at the grave of the one who was buried the day before without the Bible, songs or sermon. (R. Ottesson's letter from Verkhnii Suetuk to I. Tõnurist, 1967) 
Research into Siberian Estonians suggests that the Soviet authorities were relatively lenient towards the use of the Bible: they probably hoped that the new Soviet customs would eventually push aside the old traditions and that the younger generation will abandon the old ways and adopt the new Soviet ones. Although Rosalie Ottesson came from a traditional village community, she was at the same time an avid supporter of the Soviet regime and justifies the Christian burial of her mother in the 1960s as follows:

I was a Communist, there were four of us, sisters - my sisters were not Party members, our mother died. There was a question of how we will bury our mother, whether [to give her] a Christian or a non-Christian funeral. [...] So we concluded that there must be some consistency, most of us agreed to organise a religious funeral, and so we did. Had there been a brass band or someone singing newer songs, then we might have used them, but since there was not, we had to follow the old traditions.

(R. Ottesson's letter from Verkhnii Suetuk to I. Tõnurist, 1967)

It is known that one of Ottesson's sisters was a village burier, which was another reason why a non-religious funeral could not have been held.

In Estonia, secular funerals emerged in the Soviet period and have been arranged until the present day, side by side with religious funerals. Members of a congregation are usually buried by a local pastor, while non-religious funerals are carried out by a secular minister, often employed by the local funeral office. After the restoration of independence in the Republic of Estonia, there are also private entrepreneurs offering funeral services. In the culture of Siberian Estonians, funerals were predominantly religious, and the ceremonies were led by a local burier. The village community accepts the tradition as it has evolved.

\section{VILLAGE BURIERS IN SIBERIA}

It is known that immediately after settling in Verkhnii Suetuk, and during the period when there was no pastor in the village, baptising and funeral rituals were performed by Jüri Kuldem (Must 2012: 384). Regretfully, the author of this article has no corresponding information on other settlements in the region. During the period when vicars/schoolmasters were active in the settlements, they were the ones to perform funeral ceremonies. After the 1920s-1930s repressions of the mainly male-dominated clergy, the performing of religious rituals was taken over by village buriers, who were usually women (Jürgenson 2000: 42-44). The same situation is common to several other peoples in Russia (see, e.g., Kallatsa 1994: 26-27). The reason for that was that women were not 
directly under the threat of being deported. The repressions of 1936-1938 left no village untouched: in many Estonian villages in Siberia, nearly all adult men were deported.

The Second World War took the few remaining men from the villages to the frontline. After the war, the share of men in the villages grew, but they still remained a minority. Over time, the Estonian villages in Siberia grew accustomed to the leading role of women. Since women tend to be more conservative by nature and more prone to preserve traditions, and somebody needed to perform rituals in the community, women assumed the responsibility for carrying them out (see Korb 2004: 111-117). The required skills were passed on hereditarily. Village buriers were and still are highly aware of the importance of their responsibility and tried to improve their knowledge as best they could. One of the main problems was the scarcity of books on liturgical practices in the villages. Certainly, there were fewer such books than there were Bibles and hymnals to begin with. The majority of Estonian-language literature was destroyed during 1936-1938, the years of repressions, and very few were courageous enough to hold on to religious books; however, if they did, the books were carefully kept hidden. Thus, each and every existing book on religious rituals was sought after and borrowed in case of necessity. After the 1990s, new editions of Bibles, hymnals and other religious books were brought and sent to the Estonian villages, but books on liturgical practices for baptising and funerals were not among them. The Estonian village buriers in Siberia often kept manuscript notebooks, in which they stored the necessary prayers and songs. Even if a burier had at her disposal the notebooks of her predecessor, she still tried to copy the required prayers and songs in her own hand - for easier use. The Siberians who have been schooled in the Russian language tend to struggle with Estonian orthography, so the copied texts are often with errors and omissions.

The songs sung at funerals are usually copied from manuscript notebooks; some have been taken from hymnal sheets used at funerals in Estonia. Of the funeral songs sung by Siberian Estonians, only a few are associated with a specific part of the ritual - for example, the song "Las ma lähen...” (Let me go...) is sung when the deceased is carried outside, and the song "Mu rahukamber valmis..." (My chamber of peace is waiting...) is sung when the coffin is lowered to the grave. However, most of the songs could be sung in any order both at the wake and during the funeral. Depending on the situation, the songs may be adapted. The repertoire varies significantly from village to village. Also, the share of religious and non-religious songs differs from one village to another (see Korb 1998: 153).

Larger Estonian communities in Siberia (e.g., Verkhnii Suetuk village) have never been without a burier: 
They passed it on from generation to generation; well, they passed on the liturgical texts of funerals from one generation to the next, and so they conduct funerals. [...] They do it in Estonian. The present one has been [a burier] for as long as I can remember, but who was before her? Anni Matsi, after that the one from Ploomi, and, let's see, the fifth or sixth was Juhanna Paap, who was [a burier] for a long time. And after her, it was me, and Miina Villa is the most recent one. ERA, DH $189(5)<$ Verkhnii Suetuk v. < man, born in 1942 (2009).

Most of the buriers were elderly women, although occasionally also a middleaged woman could become one:

Oh, I don't even remember anymore when I carried out my first baptism. It seems to me I baptised the first child 42 years ago, and now buried her. ERA, DV $130<$ Verkhnii Suetuk v. < woman, born in 1920 (2000).

If someone showed interest in becoming a burier, they could learn the trade on their own:

But did anyone teach you? - No, I started to read the books myself. [...] In 1938, my father was deported; they took the Bibles and all. And so I got this urge to read them [...].

ERA, DV 130 < Verkhnii Suetuk v. < woman, born in 1920 (2000).

The understanding that a burial without a religious funeral would be a breach of the community's norms has forced some village buriers to pass on their funeral texts:

I copied these in notebooks. And gave quite many to the [Verhknaia] Bulanka village and have given these to many, so they would start to read them. I used to perform funerals in Bulanka and then I have Juhanna of Saare's ones that I have copied. So you could bury, and sing like that yourself and bury.

ERA, DV 130 < Verkhnii Suetuk v. < woman, born in 1920 (2000).

The village burier, who could feel her death approaching, sometimes chose the next burier from among the villagers, also handing over the books on liturgical practices at her disposal:

Juhanna had so many of these books, she gave them to Jaan. So that he would become the next burier. Jaan still has these books, I think. There are those about how to conduct young people's funerals and those. Books, yes, Juhanna got these from ministers in Estonia, who sent these.

ERA, DH 436 (6) < Verkhnii Suetuk v. < woman, born in 1940 (2012). 
The same Jaan, who was Juhanna's successor as a burier in Verkhnii Suetuk for a while, studied theology in Krasnoyarsk in the late 1990s and became an official pastor's assistant. He describes his journey to the profession as follows:

So the Finnish church officials came there [to Verkhnii Suetuk], and we were sending our nephew to the army. Then we started to talk and I am asking: What are you looking for? That, here's the church, right, and according to law, the church was built by the Finns, in $1888 .^{2}$ That if you want to do some work, then work and rebuild the church. There were quite many people in the village back then, and so they asked me to come to this seminary in Krasnoyarsk. [...] I was already retired, but then I attended this seminary, for a year and a half, I think. [...] It was a distance-learning course; I went there thrice a year. [...] And there it was, I completed the studies, came back and worked, I was given the position of catechesis ${ }^{3}$ and the right to perform funerals and baptisms and hold sermons. But Juhanna Paap fell ill and she was the first person to whom I gave a church funeral. Of course, I may not have performed the funerals according to all the rules. I followed the example of movies at the cinema, nobody taught me. Had I been taught to conduct funerals or baptisms? No, I was only taught theology. [...]

ERA, DH 189 (15) < Estonia, Turba < Verkhnii Suetuk v. < man, born in 1942 (2009).

And so Juhanna died and this Jaan took her to the church. And nobody else had ever taken a dead person there. But then they did. Juhanna was taken to the church, and then from there she was taken to the graveyard. [...] They objected, of course, but took her anyway. - Who objected? - Well, plemianniks ${ }^{4}$, and they were so against it, but it didn't matter.

ERA, DH 433 (8) < Verkhnii Suetuk v. < woman, born in 1934 (2012).

While in Estonia, the deceased may be sent off from both the church and home (Paenurm 1995: 47), whereas a sendoff from the church was highly uncommon in Siberian Estonians' funeral tradition. In many Estonian villages in Siberia, no church had been built; instead, they used a school which doubled as a prayer house. The burier's wish to send the former village burier off from the church met strong opposition in the village. Jaan did not stay in the job of an officiant for long, as the villagers never truly accepted him. Another obstacle to his keeping the position was that he could not sing.

In retrospect, the people of the Minusinsk region believe that "Juhanna was good at funerals, she also did it for many, many years."

ERA, DH 433 (8) < Verkhnii Suetuk v. < woman, born in 1934 (2012). 
In the meanwhile, they are pleased with their current burier, Miina: "But now we have in Suetuk, when you go, you'll definitely meet Miina. She is in the village, conducting all the burials, Miina Villa."

ERA, DH $427(25)<$ Minusinsk city < Verkhnii Suetuk v. < women in a group (2012).

\section{DEATH OF A COMMUNITY MEMBER AS A REPRESENTATION OF GROUP IDENTITY}

In a Siberian village community, the death of a community member involves not only the family and relatives of the deceased but the entire community. Villagers of more advanced age traditionally prepare for their own funeral: set aside coffin clothes (Mikkor 2001: 108; Torp-Kõivupuu 2003: 129) and money for the funeral, as is customary in Estonia. If an elderly person has no children, or they live far away, they also choose someone to arrange the funeral. Formerly, people had even their coffin boards ready; the coffin was made by local craftsmen right after the death (Korb 2004: 120). The same custom has been noted among the rural population in Estonia (Mikkor 2001: 113). Today, elderly people often complain that the procured coffin boards are not needed anymore; it is easier to buy a ready-made coffin in the city or region centre. Contemporary coffins in Siberia are covered with black or red cloth. In recent years, coffins have been equipped with handles, while earlier on a coffin was laid on a few plank boards, and was carried by ropes, or sometimes towels, as was customary among Russians (Korb 2004: 120-121). Although not common in the Estonian tradition, the Estonians in the villages of the Minusinsk region often have a cross ready before death. This is mostly an iron cross forged by a local smith. The tradition of making preparations for death has been largely upheld by the lack of adequate funeral services in the Soviet Union (Mikkor 2001: 105) and the overall deficiency of commodities.

A funeral feast is usually held in the home of the deceased. If the house happens to be too small, the deceased may be seen off from some larger neighbouring house. A dignified sendoff of the deceased is considered highly important; the funeral becomes a shared event, a demonstration of unity:

They take it to the funeral house, some give butter and cream. In Bulanka, a villager buries another, the other yet another. Whether you have a relative or not, they will still bury you.

RKM II 449, 52 (69) < Verkhnii Suetuk v. < woman, born in 1936 (1992). 


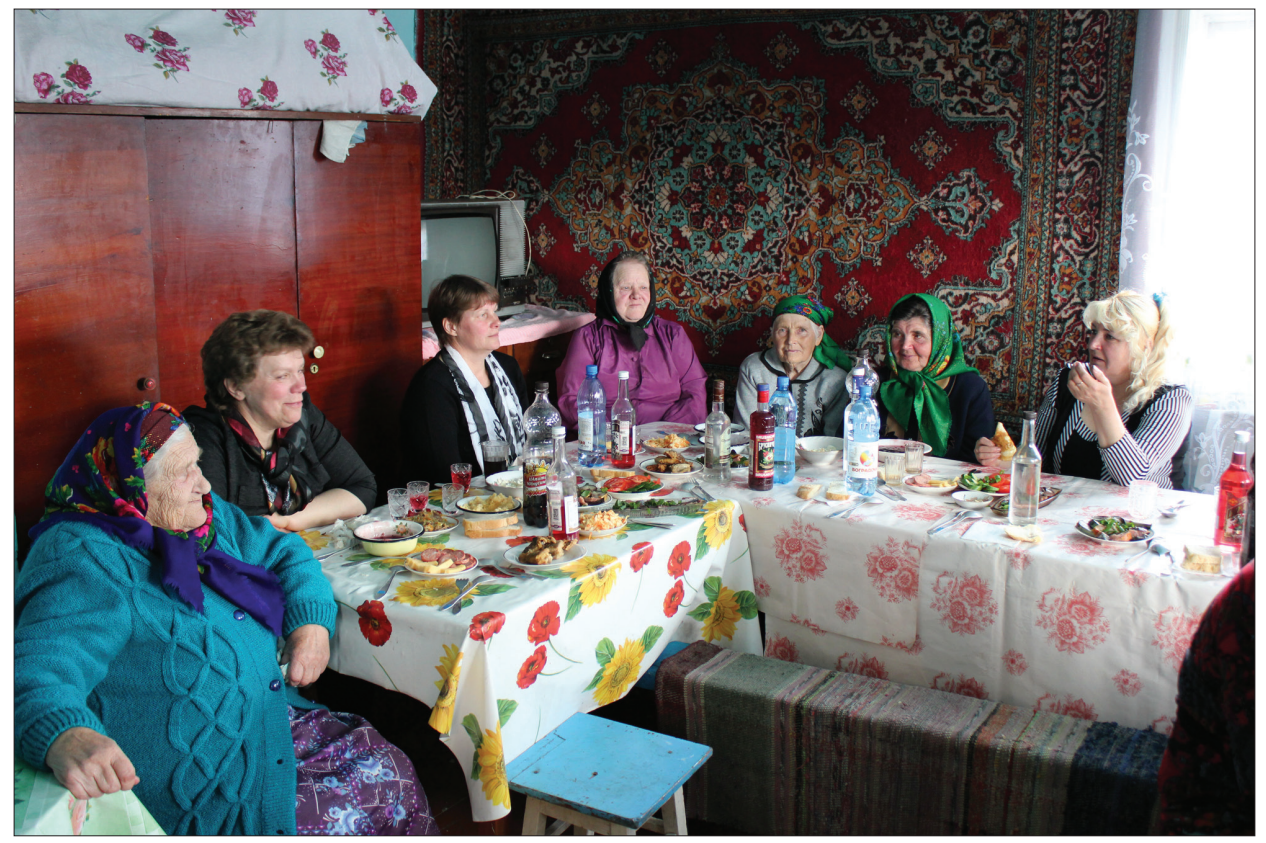

Figure 2. Women at funeral table. Verkhnii Suetuk village. Photograph by Andreas Kalkun 2012.

Bringing food does not necessarily mean that the family actually needs it: it is more the old habit of reciprocal helping, still very common in a village community. A similar helping out with food is part of the funeral tradition in southeast Estonia (Torp-Kõivupuu 2003: 73) and is known among many peoples, for instance, among the Finns (Vuorela 1977: 623). If the deceased community member came from a poorer family, the donations were larger; according to tradition, all members of the community must be sent off with dignity. This way everybody in the community contributes to the funeral feast, which is very lavish. Having a traditional funeral is a matter of prestige.

The women who are invited to prepare the funeral feast in Siberian Estonians' communities do not refuse without a good reason. In the Minusinsk region, the women who set the funeral table are called triapkas $\mathrm{s}^{5}$. These helpers are given an apron as a thank-you gift. One woman who had often been asked to help at funerals claimed that she had at least twenty aprons as gifts. But when in spring 2012, a woman who lived in Sweden and had not made it to her parent's funeral, offered second-hand clothes as a gift to the helpers, the villagers perceived it as odd. 
While in earlier times funeral guests were offered food twice both in Estonia and among Estonians in Siberia, today only one meal is served (cf. Mikkor 1992: 170-171). Among the compulsory funeral meals in Siberia is Estonian cabbage. Usually a larger animal is slaughtered for the funeral of a farmer or his wife. The ritual killing of an animal or a bird for the funeral has been observed both in Estonia and among many other nations (see, e.g., Salve 2000: 130). The funeral menu of Estonians in Siberia is more or less the same than that of any other feast held to celebrate holidays or festivities. The funeral feast that the author witnessed in Verkhnii Suetuk village in the spring of 2012 was extremely sumptuous: first noodle soup with meat balls was served, then came cutlets, mashed potatoes, jellied meat, potato sausage, and fried fish; there was white bread, herring, mackerel, and different salads on the table. A little later, prossa or millet porridge, thickened juice, tea, bliny (small buckwheat pancakes), pies, fruit, candy, and the local delicacy, cake with ground bird cherry berries, were served. Also, a larger variety of alcohol was offered (Korb 2012: 189). Given that generally only store-bought vodka is offered at the funerals among Siberian Estonians (Korb 2004: 130), at this funeral there was also self-made moonshine, sloe brandy ${ }^{6}$ and cranberry wine. The deceased had made arrangements with the neighbour five years before, upon her leaving to the retirement home, and had even given the neighbour money to pay for the funeral. Now the person who arranged the funeral made everything possible to please the villagers.

Siberian Estonians do not leave an empty seat at the table for the deceased, as is traditional in Estonia. If in Siberia there is less room at the table, funeral guests take turns eating. The guests leave immediately after the meal. In former times, funeral feasts lasted longer: the guests were offered a hot meal upon their return from the graveyard, after which they went home to tend to animals or cattle and returned later for the evening tea. A characteristic feature of a funeral feast in Verkhnii Suetuk village is that women and men are seated at different tables; the custom has probably roots in Christian culture.

It is important to observe ancestral traditions in performing funerary and death-related rituals. For example, the funeral tradition of Estonians in the Minusinsk region entails a custom of turning around the benches, on which the coffin was placed, after the deceased has been taken outside. The meaning behind this magic-protective ritual - most likely, to avoid a new occurrence of death in the house - is no longer known, but the ritual is performed nevertheless.

While today Estonians in Siberia believe that it is bad luck to dig the grave of one's close relative, in earlier tradition, both in Siberia and Estonia, gravediggers were often relatives of the deceased (Korb 2004: 122). Estonians in the 
Minusinsk region choose gravediggers from among the members of the community. The diggers do not get paid for the job, but are given a bottle of vodka, and often also a pair of knitted mittens in return for the service. In Verkhnii Suetuk village, which has the oldest brass band in Siberia (established in 1901, see Alaverdian 2001), the deceased is sent off to the accompaniment of brass band music. The band is not paid for playing at the funerals that are held in their home village.

On the day following the funeral, a small group of people traditionally visit the grave, saying prayers and singing funeral songs.

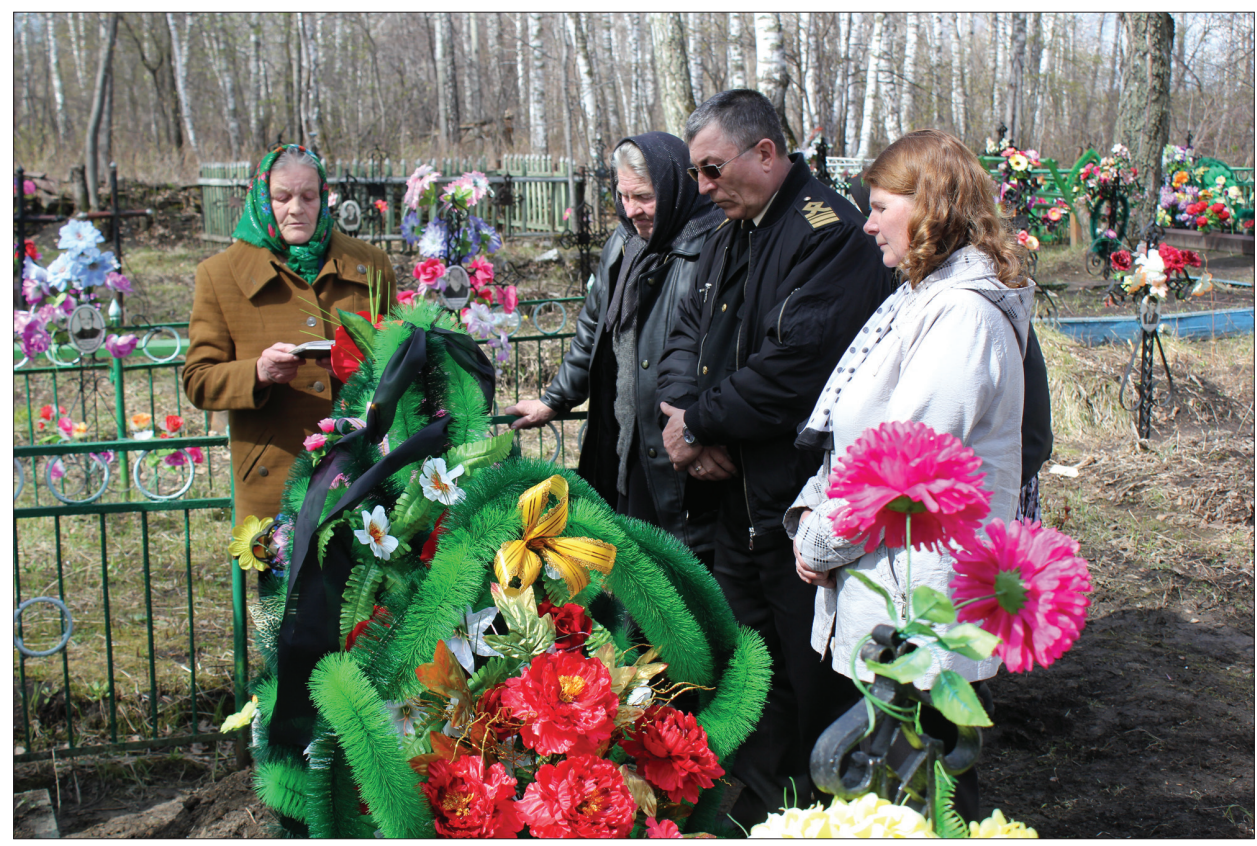

Figure 3. On the day following the funeral, a group of people visit the grave, saying prayers and singing funeral songs. Photograph by Andreas Kalkun 2012. 


\section{CHANGES IN THE FUNERAL TRADITION IN RECENT DECADES}

These days, the population of Estonian villages in Siberia is rapidly getting older and smaller. While social services in Russian villages are quite efficient (a caretaker is appointed by the village council to help an elderly person cope in daily life), adult children have the responsibility to take care of their aged parents. In the tough Siberian climate, people are accustomed to maintaining close contacts, and attending relatives and neighbours is taken for granted. A retirement home is considered to be the last resort if an elderly person is in need of constant care and has no children living nearby or none at all.

Given that many young people, who find little to do in the villages, have moved to the cities and towns, their aged parents have to spend their final days of life away from their home village. A beloved home village and house is left behind to move into a narrow space. The changed living conditions have also introduced changes in the funeral tradition: a dead body cannot be kept in a city apartment, the stairways of apartment blocks are too narrow to transport a coffin, etc. Also, the requirement imposed in Russia a few years ago that all the deceased must undergo autopsy further alters the tradition. Among the older generation, the forced autopsy requirement has elicited strong opposition. Once a deceased has been taken away from home, the washing and dressing of the body is often arranged by the funeral services, not by relatives.

The villagers who have moved to the city are often faced with the problem of either burying the deceased relative in the cemetery of the city or town where they live, or in the graveyard of the home village. After careful consideration of the pros and cons, decisions are made either way. The elderly, however, wish to be buried in the home village, next to their 'own' people. The ties connecting people with a location during their lifetime are believed to be stronger than death (Jürgenson 2004: 147). There are many examples of people living in exile who wish to be buried in the soil of their birth country (see, e.g., Grafik 1998: 310). The Estonians of the Minusinsk region, who have lived in Siberia for five to six generations, tend to view as their home Siberia, rather than Estonia. There are, of course, pragmatic considerations behind the decisions. Several aged villagers discussed whether someone's final resting place may depend on the weather conditions at the time of death. In cold winter weather it would be virtually impossible to fulfil the wish of the deceased to be buried in the home village graveyard, which is why the choice is made in favour of the cemetery nearest to the last place of residence. For example, the graveyard of Motorskii, a Russian village with a relatively large population of Estonians from Verkhnaia Bulanka village, has a separate section for Estonians (Jürgenson 2004: 145); this way the people of the village stay together even outside their home village. 
The younger generation prefers cemeteries in larger towns and cities also for practical reasons: this makes it easier to take care of the graves and visit the cemetery on commemoration days.

From summer 2007, the Evangelical Lutheran Church of Ingria takes care of the religious life of Estonians in the Minusinsk region. There is a Lutheran pastor in Minusinsk and also in the district centre Karatuzskoe, but visits to the Estonians in Verkhnii Suetuk, Verkhnaia Bulanka and the surrounding Russian villages are also made. The pastors do not speak Estonian, so the communication takes place and services are held in Russian. An Estonian pastor visits the Estonians of the region once a year, around St. John's Day. For Estonians it is important that the burial service of their compatriot is held in their mother tongue. Even though not all the funeral guests speak Estonian these days, a Russian pastor is not invited to officiate the funeral ceremony. The situation is quite analogous to that of Karelian Finns, who have resettled in Finland (see Davydova 2005: 1). In smaller villages and the surrounding Russian settlements (e.g., in Verkhnaia Bulanka with the population of about 40, and in Motorskii village), with no village burier any longer, a burier is summoned from Verkhnii Suetuk village. And should that prove impossible due to harsh weather conditions or for some other reason, the funeral is held by saying a prayer in Estonian.

Furthermore, the number of people who know and can sing Estonian songs is quite small in the villages:

There used to be so many singers. But by now they are all dead. Miina was one of them, how well she sang. And then there was Anni, Anni Uhvelt. [...] And then, Kostia, when he still came, then at the end with Miina, vaikka there are no other singers, but the two of them, they sang so beautifully. ERA, DH 433 (7) < Verkhnii Suetuk v. < woman, born in 1942 (2012).

In these days there are fewer and fewer people to officiate a funeral ceremony among the Estonians of the Minusinsk region, and so the tradition is broken with and changed. The existing village buriers are occasionally criticised as one or the other is not saying a prayer right, although the criticisers hardly know what the right way would be. Some villagers are concerned that when they die, there might not be a burier any more. For them, the most important thing is to preserve the tradition, and, compared to this, ethnic and in some cases confessional considerations are secondary. Since the tradition requires a religious funeral, also a local Russian-language Lutheran pastor may be called to officiate the funeral these days. On rare occasions a Lutheran Estonian has been buried by an Orthodox priest. At the same time, it is possible that a deceased, an Orthodox from a Russian village, is buried by an Estonian village 
burier, who performs the ceremony according to the Lutheran tradition and in Estonian.

In some Estonian communities in Siberia, for example, in Verkhnii Suetuk village, people used to visit the graveyard on Sundays. They visited the graves of relatives and acquaintances, often touching the cross or the grave monument. Women sat on a bench near a grave or the graveyard gate, singing death and funeral songs.

In earlier days, Estonians of the Minusinsk region used to celebrate only a year's passing from someone's death. By the present day, Siberian Estonians have adopted commemoration days, previously unknown to them, from the Orthodox Russians as part of their tradition. Thus they now celebrate the passing of 9 days, 40 days, and half a year from someone's death. On these commemoration days, a small group of the closest relatives visit the graveyard. Such visits may be quite complicated during muddy seasons, when the roads are falling apart. Most villagers and closer relatives who live elsewhere gather in the home of the deceased; people wear festive clothes: men are dressed in suits and white shirts, women wear mostly dark-coloured dresses. First they toast with a shot of vodka to commemorate the dear departed. When there is traditional food on the table (bliny with honey or kutya ${ }^{8}$ ), the guests have some of that. Then follows a hot meal and snacks and salads. In a few hours the commemoration meal is over.

The most important commemoration day of Estonians in Siberia used to be St. John's Day, and they did not have the custom of eating at the grave or leaving food there (unlike the Setos in Siberia). Visiting the graveyard during Whitsuntide and Easter was common also for the Orthodox Setos in Estonia (see Hiiemäe 1984: 213). In these days, Siberian Estonians also go to the graveyard on Whitsuntide and Easter. Even on May 9, the Russian national Victory Day, Estonians in Siberia traditionally commemorate the male relatives in graveyards, even if the relation of the deceased to the war is insignificant. Following the example of Russians, Estonians in Siberia have started to celebrate roditelski, the commemoration of parents, which is a work-free day in Russia.

Estonians in the Minusinsk region have an ambivalent attitude towards bringing food to the graveyard: some think that there is no need to take anything along, others pack a whole meal to go. In these days, some Estonians in Siberia place candy or cookies and various pastries on the graves. A glass of strong alcohol is placed on the graves of male relatives, and sometimes vodka is poured right on the grave.

The custom of burning candles on graves, which is becoming increasingly popular in Estonia, is gaining ground also in Siberia. Earlier on, candles were not even available in local stores. Over time, people have started to visit grave- 
yards on Christmas Eve and on New Year's Eve. Access to a village graveyard may be difficult in the winters with too much snow as the roads are cleared only for funerals.

\section{CONCLUSION}

Compared to other family traditions, the traditions related to death and funerals tend to be far more conservative and stable. The funeral traditions of Estonians living in the Minusinsk region in Siberia offer an insight into how a community functions under the collapse of a religious system: which parts of it are preserved and which are bound to change. In general, Estonians in Siberia wish to be given a religious funeral, following the Lutheran tradition and in the Estonian language, even though the social situation has not always favoured this. After the local clergy was deported, funeral ceremonies became the responsibility of non-professionals, mostly older women who were not under direct threat of being deported, and so it became part of women's tradition. Village buriers were more or less familiar with the community's funeral tradition, which was passed on from one person to the next by sharing experience, by word of mouth, if there was no literature available. Buriers are the primary shapers of a community's funeral tradition, but they have no authority without the acceptance of community members.

Collective ritual practices most directly serve the function of uniting the community. A group's identity clearly comes to the fore in funeral culture; members of the group try to act according to the ways of ancestors, and helping each other is considered important. Funeral culture is largely under the social control of the aged: deviations from established customs are frowned upon and people find it safer to follow the usual practice. The observation of old traditions gives the relatives of the deceased some peace of mind: by doing as always, the dead are believed to be pleased. On the one hand, the funeral and death tradition of Estonians in the Minusinsk region reflects the wish to continue the legacy of ancestors, but, on the other hand, in today's multicultural world people inevitably borrow some elements of tradition from the neighbouring, often dominant, culture: traditional Russian meals are served at the funeral feast, mourners observe the passing of 9 and 40 days from death, people visit the graveyard on Easter holidays and Whitsuntide, on May 9, and on the roditelski, the parents' commemoration day. The Estonians who were born and raised in the villages of the Minusinsk region are more often buried in the cemeteries of the city of Minusinsk or the district centre Karatuzskoe. The graves are beginning to look 
more like those of the local Russian population: they are surrounded by iron fences, grave monuments and wreaths of artificial flowers are made by local craftsmen and differ considerably from what is conventional in Estonia.

When discussing the funeral tradition, Estonians in Siberia clearly distinguish between the culture of 'us' and the culture of 'others', and are well aware of foreign elements in the tradition. The older generation prefer to preserve the ways of their forefathers and are more reluctant to adopt foreign traditions. In a multicultural environment, however, the adoption of some elements of the neighbouring tradition is inevitable. The results of such integration become more evident among mixed families, but also among Estonians living in cities and multi-ethnic villages. The levelling tendency of funeral traditions is further evidenced by the reciprocal summoning of buriers of different religious backgrounds and nationalities, in some instances also by officiating the funeral ceremony in Russian, which has already become a language to bridge the generation gap.

\section{ACKNOWLEDGEMENTS}

This work was supported by the Estonian Research Council grant number 9066 "Ethnic and National in Estonian Diaspora Communities", and by the institutional research funding IUT22-4 "Folklore in the Process of Cultural Communication: Ideologies and Communities" of the Estonian Ministry of Education and Research.

\section{ABBREVIATIONS}

ERA, DH - Estonian Folklore Archives, digital sound recordings on hard disc ERA, DV - Estonian Folklore Archives, digital video recordings RKM - Estonian Folklore Archives, manuscripts (1940-1995) 


\section{NOTES}

1 Igor Tõnurist and Rosalie Ottesson met in 1965. Tõnurist visited the Estonian settlements in the Minusinsk region of Krasnoyarsk Krai as an ethnography student of the Moscow University (Korb 2013: 10).

2 The oldest extant Lutheran church building in Siberia is situated in Verkhnii Suetuk village.

3 Pastor's assistant, catechism teacher, in Lutheran church.

4 Russ. plemiannik means 'nephew' or 'niece'.

5 Russ. striapat' means 'prepare' or 'bake food'.

${ }^{6}$ Russ. boiaryshnik means 'blackthorn'.

7 Fin. vaikka means 'although', 'even though'.

8 Russ. kutya - rice or barley cooked in honey, or with raisins added; a common Orthodox funeral food.

\section{REFERENCES}

Alaverdian 2001 = Alaverdian, L. (comp.) "I umiral i vozrozhdalsia vnov..." 100 let Verkhnesuetukskomu natsional'nomu narodnomu dukhovnomu orkestru. [100th Anniversary of Upper Suetuk National Brass Band.] S. Karatuzskoe.

Davydova, Olga 2005. Rituaali, identiteetti ja ylirajaisuus. Joitakin ajatuksia paluumuuttajan hautajaisista. [Ritual, Identity and Transnationalism: Some Thoughts on the Funeral of a Return Migrant.] Elore, Vol. 12, No. 1, pp. 1-22. Available at http://www.elore.fi/arkisto/1_05/dav1_05.pdf, last accessed on April 10, 2014.

Ehala, Martin 2010. Keel ja ühiskond. Väliseesti kogukondade jätkusuutlikkusest. [Language and Society: The Sustainability of Estonian Diaspora Communities.] In: Kristiina Praakli \& Jüri Viikberg (eds.) Eestlased ja eesti keel välismaal. [Estonians and Estonian Language Abroad.] Tallinn: Eesti Keele Sihtasutus, pp. 59-91. Available at http://www.eki.ee/books/eekv/EEKV.pdf, last accessed on April 10, 2014.

Giles, Howard \& Bourhis, Richard Y. \& Taylor, Donald M. 1977. Towards a Theory of Language in Ethnic Group Relations. In: H. Giles (ed.) Language, Ethnicity and Intergroup relations. London: Academic Press, pp. 307-348. http://dx.doi. org/10.1016/0024-3841(79)90051-2.

Grafik, Imre 1998. Nation, Nationality, National Minority. Acta Ethnographica Hungarica, Vol. 43, Nos. 3-4, pp. 307-325.

Greverus, Ina-Maria 1987. Kultur und Alltagswelt. Eine Einführung in Fragen der Kulturanthropologie. Frankfurt am Main: Institut für Kulturanthropologie und Europäische Ethnologie.

Hall, Stuart 1999. Identiteetti. [Identity.] Tampere: Vastapaino. 
Heikkinen, Kaija 1985. Folklorismin monet muodot. Esimerkki Neuvostoliiton juhlaperinteestä. [Some Forms of Folklore.] Tiede ja Edistys, Vol. 2, pp. 119-131.

Hiiemäe, Mall 1984. Eesti rahvakalender III. [Estonian Folk Calendar.] Tallinn: Eesti Raamat.

Jetsu, Laura 2001. Kahden maailman välillä. Etnografinen tutkimus venäjänkarjalaisista hautausrituaaleista 1990-luvulla. [Between Two Worlds: Ethnographic Study on the Funerary Rituals of Karelian Finns in the 1990s.] Suomalaisen Kirjallisuuden Seuran Toimituksia 853. Helsinki: Suomalasen Kirjallisuuden Seura.

Jürgenson, Aivar 2000. Kirik ja kool Siberi eesti asundustes. [Church and School in Estonian Settlements in Siberia.] Acta Historica Tallinnensia, Vol. 4. Tallinn: Teaduste Akadeemia Kirjastus, pp. 31-48.

Jürgenson, Aivar 2002. Siberi eestlaste territoriaalsus ja identiteet. [Territoriality and Identity of Siberian Estonians.] Tallinna Pedagoogikaülikool. Humanitaarteaduste dissertatsioonid 7. Tallinn: TPÜ Kirjastus.

Jürgenson, Aivar 2004. Kalmistu kodupaiga sümbolina: Siberi eestlaste näide. [Cemetery as a Symbol of Home: On the Example of the Estonians in Siberia.] Mäetagused, Vol. 25, pp. 143-156. doi:10.7592/MT2003.25.jyrgenson.

Kallatsa, Miika 1994. Karismaattiset naiset - Inkerin kirkon pelastus. [Charismatic Women: Ingrian Church Redemption.] Verso, Vols. 6-7, pp. 26-27.

Korb, Anu 1998. Siberi eestlaste lauluvara. [Songs of Estonians in Siberia.] In: Astrid Tuisk (ed.) Eesti kultuur võõrsil: Loode-Venemaa ja Siberi asundused. [Estonian Culture Abroad: Estonian Settlements in Northwest Russia and Siberia.] Tartu: Eesti Kirjandusmuuseum, pp. 143-157.

Korb, Anu 2004. Siberi eestlaste surma- ja matusekombestikust 20. sajandi viimasel kümnendil. [On the Death and Funeral Tradition of Estonians in Siberia during the Last Decade of the 20th Century.] Mäetagused, Vol. 25, pp. 103-142. doi:10.7592/MT2003.25.anudkorb.

Korb, Anu 2008. Eestlased Venemaal ja taasiseseisvunud Eesti. [Estonian Emigrants in Russia and the Newly Independent Estonia.] In: Kristi Anniste \& Kaja KumerHaukanõmm \& Tiit Tammaru (eds.) Sõna jõul: Diasporaa roll Eesti iseseisvuse taastamisel. [By the Power of Word: The Role of Diaspora in the Restoration of Independence in Estonia.] Tartu: Tartu Ülikooli Kirjastus, pp. 53-72.

Korb, Anu 2012. Eestlased ja setud Krasnojarski krai külades. [Estonians and Setos in the Villages of Krasnoyarsk Krai, Russia.] Mäetagused, Vol. 52, pp. 186-189. Available at http://www.folklore.ee/tagused/nr52/u01.pdf, last accessed on April $11,2014$.

Korb, Anu 2013. Rahvaluule osakonna Siberi kaastöölise Rosalie Ottessoni ja teaduritearhivaaride dialoog aastatel 1969-1976. [Researchers-Archivists and Siberian Correspondent Rosalie Ottesson: A Dialogue from the Years 1969-1976.] Mäetagused, Vol. 54, pp. 7-26. doi: 10.7592/MT2013.54.korb.

Kulu, Hill 1992. Eestlased maailmas. Ülevaade arvukusest ja paiknemisest. [Estonians in the World: Population and Geographical Locations.] Tartu: Tartu Ülikooli Kirjastus.

Mikkor, Marika 1992. Kaukaasia eestlaste matusekombestikust. [Funeral Traditions of Estonians in the Caucasus.] Eesti Rahva Muuseumi aastaraamat XXXIX [The Yearbook of the Estonian National Museum], pp. 167-186. 
Mikkor, Marika 2001. Muutuvast matusekombestikust linnas ja maal. [The Changing Funeral Tradition in Towns and Countryside.] In: Terje Anepaio (ed.) Eesti Rahva Muuseumi aastaraamat XLV [The Yearbook of the Estonian National Museum], pp. 103-146.

Must, Aadu 2012. Siber ja Eesti. Jalaraua kõlin. [Siberia and Estonia: The Rattle of Shackles.] Tartu: Tartu Ülikooli Kirjastus.

Paenurm, Peeter 1995. Luterliku matusetalituse kord ja praktika Eestis. [Liturgy and Practices of Lutheran Funerals.] Diploma work. Tallinn: EEKL Usuteaduste Instituut.

Pentikäinen, Juha 1990. Suomalaisen lähtö: Kirjoituksia pohjoisesta kuolemankulttuurista. [Finnish Death: Writings on Nordic Death Culture.] Suomalaisen Kirjallisuuden Seuran toimituksia 350. Helsinki: Suomalaisen Kirjallisuuden Seura.

Postimees 1899 = Eesti lastest Siberis. [About Estonian Children in Siberia.] Newspaper Postimees, No. 196, September 6, p. 1. Available at http://dea.nlib.ee/fullview.ph p?pid=s277970\&nid=3717\&frameset=1, last accessed on July 2, 2014 .

Ristolainen, Tiia 2004. Surmakultuuri suundumused tänapäeval: avalik ja privaatne. [Contemporary Tendencies in Death Culture: Public and Private.] Oppetatud Eesti Seltsi Aastaraamat 2002. [The Yearbook of the Estonian Learned Society.] Tartu: Õpetatud Eesti Selts, pp. 244-266.

Salve, Kristi 2000. Mõningaid tähelepanekuid tavanditoitudest: diferentseerimine piirkonniti ja üldistumine tavanditi. [Observations about Ritual Foods: Regional Differentiation and Generalisations.] In: Mare Kõiva (ed.) Sator: Artikleid usundi-ja kombeloost II. [Sator: Articles on Religion and Customs.] Tartu: EKM Rahvausundi ja meedia töörühm, pp. 121-140. Available at http://www.folklore. ee/rl/pubte/ee/sator/sator2/, last accessed on April 11, 2014.

Torp-Kõivupuu, Marju 2003. Surmakultuuri muutumine ajas: ajaloolise Võrumaa matusekombestiku näitel. [Changes in Death Culture in Time: On the Example of Historical Võru Region.] Tallinn: Tallinna Pedagoogikaülikooli Toimetised. Humaniora A 22.

Turner, Victor 1969. The Ritual Process: Structure and Anti-Structure. Chicago: Aldine. Viikberg, Jüri \& Vaba, Lembit 1984. Siberi põhjaeestlasi kõnetamas. [Conversations with North Estonians in Siberia.] Keel ja Kirjandus, No. 3, pp. 145-156.

Van Gennep, Arnold 1977 [1960]. The Rites of Passage. London: Routlege and Kegan Paul. Vuorela, Toivo 1977. Suomalainen kansankulttuuri. [Finnish Traditional Culture.] Porvoo \& Helsinki \& Juva: Werner Söderström Osakeyhtiö. 